\title{
ELIZA KRUPIŃSKA
}

https://orcid.org/0000-0002-1132-1817

The Pontifical University of John Paul II in Kraków

Interuniversity Institute of Church Music

\section{Back to Structures and Signs - Remarks on the Possibilities of Structural Aesthetics of Music}

\begin{abstract}
Is it possible to talk of mental patterns underlying aesthetic reflections, and has the constant recurrence of particular ideas in the area of aesthetics some deeper explanation? Structural aesthetics of music is an authorial research conception which enables interpretation of phenomena from the area of history of music aesthetics, and in this way provides its systematised picture. The conception uses the ideas of structural linguistics: binary phonological opposition and the historicalliterary process in the approach of Jan Mukařovský. The article also contains an example of using this conception in relation to the aesthetics of antiquity (sophists, Plato, Aristotle), Descartes and impressionism.
\end{abstract}

KEYWORDS: aesthetics, structuralism, culture, semiotics, Mukařovský, Jakobson, Plato, Aristotle, Descartes, impressionism, symbolism

It is a puzzling phenomenon that certain issues in the history of aesthetics keep recurring. While the cultural landscape keeps changing in the consecutive epochs, questions once posed return to seek ever new answers. The question of the essence of beauty, its sensory or intellectual nature, in mental space encounters reminiscences of aesthetic stances and orientations. This state of affairs allows one to hypothesise that the history of aesthetics might be governed by some regularities. Can one talk here of mental patterns underlying aesthetic reflection, and does the constant recurrence of particular ideas in the area of aesthetic have some deeper explanation? Perhaps answers to the questions formulated here require a specific approach to issues of the aesthetic, one that would also represent a specific 'thinking style', to use Ludwik Fleck's term. ${ }^{1}$ This article presents the premises of an authorial research conception, which in the frame of selected concepts makes it possible to interpret aesthetic thought,

\footnotetext{
${ }^{1}$ Ludwik Fleck (1896-1961) - Polish microbiologist, author of many important works on the philosophy of science.
} 
thus providing it with a systematised picture. The conception in question will be referred to as structural aesthetics, in view of its two fundamental components, ideas deriving from structural linguistics: binary phonological opposition and Jan Mukařovský's historical-literary process.

There is nothing new about the accusation of drawing on conceptions which are outdated and now abandoned. In the case of structuralism, which provides the canvas for the reflections presented here, this accusation does not seem justified, and the principles adopted on this issue can be expressed as follows:

- firstly, there is a difference between using selected ideas of structuralism (which is the case in the conception presented here) and between 'resuscitation' of structuralism in its orthodox form;

- secondly, towards the end of the 1970s, structural semiotics gradually limited its expansion into humanities, but the tools produced by linguistics continue to provide an interesting pool of methodological possibilities.

\section{The axiom of homology}

The standard justification for using the tools of linguistics in the area of study of art (and not only) is the so-called axiom of homology, which has its origin in the views of Roman Jakobson. According to Jakobson, there is no cause-effect relationship between psychoneurological processes and language which as a model would realise itself in the world of purely physical phenomena, but it is a relationship consisting in the fact that language is a reflection of psychoneurological rules. In other words, the psychoneurological and linguistic levels are linked by isomorphism.

Since analogy of form is technically referred to as homology, we might say that Jakobson even at this point had already formulated a limited axiom of homology. ${ }^{2}$ Limited, since Jakobson acknowledges a formal analogy between structural levels of language on the one hand (phonemic, syntactic and semantic) and - more importantly for the proposal presented here - analogy of form between linguistic and psychogenetic structures.

On the other hand, Claude Lévi-Strauss carries out a decisive expansion of the axiom of homology. He talks of detailed reflection of reality in conceptual (linguistic) forms, which he regards as a distinguishing feature of the human mind. In the technical language of logicians one might express it as follows: language and world are indistinguishable as to structure. ${ }^{3}$

\footnotetext{
2Jakobson does not use the terms 'homology' or 'isomorphism'; on the other hand, he uses the term 'correlation'.

${ }^{3}$ This is also the Kantian position, but it differs somewhat from the Kant's original idea. Firstly, the categories of mind which shaped the reality dealt with by man came, according to Kant, not from experience but were given a priori as a condition of its possibility. Secondly, Strauss replaces mental categories with linguistic categories.
} 


\section{Components of structural aesthetics - binary opposition and Mukařovský's concept of historical-literary process}

As has been said earlier, the proposed conception of structural aesthetics is inspired by the ideas of structuralism: binary phonological opposition and Mukařovskýs historical-literary process. Both ideas require detailed commentary.

Adopting Strauss's views on the linguistic character of cultural reality, it is reasonable to ask about the existence of potential regularities at the root of aesthetic thought which would direct its development. If at a deep level all artefacts really demonstrate a linguistic character, then these regularities should be sought among the universal features of language. The fundamental property of language discovered by research into its phonological structure is the binary phonological opposition. We should remember that the phoneme is the smallest unit of the language system which allows one to recognise the meaning of a word (Szymańska, 1980). A phoneme is constituted by a set of features, such as being sounded or unsounded, hard or soft. These are the phoneme's constitutive and distinctive features in the phonological system of a language. However, the most important thing is that the phonemic features arrange themselves into opposing pairs, forming what is known as binary oppositions. Identification of a specific phoneme is possible only on the basis of difference and opposition of features which, in a final analysis, determine the particular meaning. The phenomenon of distinctive features played an important part in research into semiotic systems in the area of culture. For Jakobson, and above all for Strauss, binary opposition was the basis for describing anthropological phenomena (Strauss used binary opposition to investigate such cultural aspects as food preparation, kinship systems and mythology).

Mukařovskýs views were rooted in the principles of Russian formalism, but underwent vibrant development under the influence of the structuralism of Prague school. ${ }^{4}$ One of the many issues discussed by Mukařovský was the idea of historical-literary process. In the approach of the formalists, the development of literature was understood as evolution of a system directed by its internal laws. According to Mukařovský, the process of literary development took place within reach of not one but two forces: to the forces within the system, which took account of the autonomous needs of literature, he added external forces. The latter, which he presented as part of his ideas on the sociology of poetic language (Uwagi o socjologii języka poetyckiego / Remarks on the sociology of poetic language), were the result of the influence of society and of areas of culture outside of literature.

\footnotetext{
${ }^{4}$ It is worth mentioning that Mukařovský was a student of Hostinský, who in turn had been a student of Dilthey. There is thus nothing surprising in the presence in Mukařovskýs conceptions of elements of nineteenth-century philosophical thought. Historical sensitivity and dialectical approach to phenomena are undoubtedly among these elements.
} 
In order to understand why Mukařovský attached such great importance to the influence of these external forces, one needs to refer to two fundamental theses characterising his attitude to the issue which he described as the sociology of the poetic language. Firstly, the concept of cultural series. Mukařovský regarded language, but also science, politics and art, as a product of collective consciousness. We find here echoes of the ideas of Ferdinand de Saussure, but perhaps above all those of Marcel Mauss and Émile Durkheim. A cultural series will thus not be a product of an individual, unitary mind, but a social product of a systemic character. Secondly, links between cultural series are structural, and not genetic. Following Mukařovský (1970, p. 166), we can describe these links as purposeful, dynamic and mutual, and not one sided and not of the cause-result nature. This means that movements in one series supervene (excite) on movements in one or more other series. Cultural series which influence literature are described by Mukařovský generally as social life, or simply society. ${ }^{5}$

We can thus describe Mukařovskýs theory of literature as having a sociological, or even interdisciplinary direction and, bearing in mind his interest in general aesthetics, this also applies to his theory of art.

\section{Structural aesthetics - examples of application}

Two constitutive ideas of structural aesthetics have now been discussed. It remains to present concrete solutions. Binary opposition is regarded as a force which generates and shapes the history of aesthetics, taking the form of two 'elements' which are always in a state of friction. An analysis of the history of aesthetics inclines one towards the conclusion that these elements might be 'reason' and 'senses'. On the other hand, the interference of cultural series is related to the perception of aesthetic reflection in the perspective of influences and relationships. I emphasise, following Mukařovský, that we are not talking about one-sided relationships. We are still talking about structural interference of aesthetics and other cultural and social phenomena.

A few examples of structural aesthetics approach will allow us to illustrate the functioning of the opposition reason/senses. It should also be noted that it is not the aim here to enumerate specific positions which may be ascribed to the categories of 'reason' or 'senses', but to show how the opposition steers the course of aesthetic thought and directs its dialectics.

The earliest theoretically prominent opposition between reason and senses is the case of the attitudes of the Pythagoreans and the sophists. The Pythagoreans represent extreme, since quantitative, aesthetic rationalism, while sophists re-

${ }^{5}$ Janusz Sławiński (1970, pp. 12-13) characterises Mukařovský's stance regarding the structural links between literature and society in this way: 'He argued that literature penetrates social life through its own features which determine its identity; on the other hand, social conditions may effectively influence literature in so far as they are «translated» into its language. The process of literature development from this point of view would thus be a continuous socialisation of that which is specifically literary, and at the same time continuous transposition of social life into the language of literature'. 
gard beauty as a phenomenon above all sensory, relative and subjective. The opposition between Pythagoreans and sophists is absolute, i.e., beauty understood as something expressible quantitatively excludes the possibility of understanding beauty in a qualitative-sensory manner, and vice versa.

This is the state of affairs encountered by Plato, who resolves the conflict between the two positions by excluding the sensory interpretation and building aesthetics purely on the foundations of reason. However, by then it is a different version of the rational position, not as one-sidedly quantitative as in the case of the Pythagoreans, since in Plato we find two definitions of beauty within the framework of one aesthetic. On the one hand, it adopts the Pythagorean definition of beauty in terms of numbers, but alongside it discovers the metaphysical conception of beauty as an idea, i.e., pure, original quality - an abstract quality accessible to the mind. Thus in taking into account the qualitative dimension of beauty, Plato also takes into account the postulates of the sophists whose ideas, as is well known, he was vigorously opposed to. Plato's position is rationalistic: analytic and discoursive reason (Gr. logos; Lat. ratio) is supplemented by synthetic and intuitive reason (Gr. nous; Lat. intellectus). Beauty in its quantitative aspect will be accessible to the first, and in the qualitative one - to the second.

With Aristotle, the concrete-sensory aspect of beauty will be brought back and enhanced. Still within the rationalistic position, Aristotle will take into account and stress the sensory element associated with, for example, perception of music; he will link inner sensory response with the idea of katharsis.

Another example of the opposition reason/senses are the aesthetic-musical views of Descartes. His Compendium musicae from 1618 presents the Pythagorean theory, but on the question of judgment of beauty Descartes combines the conception of music in terms of number with observation and experience of the senses. According to him, beauty depends on two things: the object's inner proportions and its adaptation to the perceiving sense. From around 1630 we may note the evolution of Descartes' aesthetic views. The measure of beauty in music is purely the pleasure derived from it by the senses, and the rational element is positively excluded. While musical emotion as passion of the soul is not subject to rationalisation, it is not totally separate from the mind. Individual disposition of the mind, its memory, mean that in Descartes' approach beauty is subjective and relative.

The examples cited above demonstrate the polarization of aesthetic positions, determined by the poles of reason and senses. At this point, it is necessary to recall an additional and semiotic justification for the choice of the latter, which is not only supported by private and subjective observation of the development of ideas about beauty. In the 1980s, the subject of research of the Moscow-Tartu school was neurosemiotics. The starting point for formulating theses concerning the development of culture was the phenomenon of functional asymmetry of the cerebral hemispheres. Semioticians, incl. Vyacheslav Ivanov or Yuri Lotman, formulated their views in the light of the belief of cooperation of the left hemisphere (dominant, controlling language and logical operations) and the right hemisphere (controlling visual and auditory images). Creative thinking was the result of the correlation of both hemispheres: the former generated a rational 
model of the world, the latter its sensual and iconic image (Żyłko, 2009, pp. 48-49). It is important for our considerations that Lotman put forward a hypothesis - supported by the already mentioned axiom of homology - about an analogy linking the way the brain functions and the processes governing culture. The development line of culture was conditioned by the influence of two opposing tendencies, which Lotman called, respectively, left-hemispherical and right-hemispherical. The left-hemispherical tendency meant closing oneself to a given semiotic model; in a sense, one's detachment and isolation from the reality in which one functioned. The right-hemispherical tendency is the other way around: the semiotic model showed a strong bond with non-textual reality; 'It was filled with the blood of real matters and needs of man and society' (Żyłko, 2009, p. 50). In Lotman's interpretation, the static period of culture was associated with the balance of both tendencies, and the dynamization of culture and its development with the domination of one of them. Simplifying the matter, but also avoiding 'vulgarization' of considerations (by simply projecting the idea of the Moscow-Tartu school onto the methodological proposal presented here), it can be said that in the case of the left-hemispherical tendency Lotman pays attention to a high degree of abstraction and intellectualization of the cultural model, and in the case of the right-hemispherical tendency - to its practical, experimental and humanistic dimension. The binary opposition of reason/ senses indicated by me shows convergence with the ideas of Lotman's neurosemiotics and his observations on the development of culture.

It is now time for an example of the interference of cultural series. An interesting example is provided by musical impressionism, or perhaps - as Stefan Jarociński (1966) would like to call it - musical symbolism. Talking about the interference of cultural series, the problem is to find a phenomenon that excludes the genetic relationship (cause-and-effect) connecting the selected series and shows their structural relationship. We are therefore talking about a situation where shifts in one series cause shifts in another. The symbolist concept of poetry as a statement referring to a vague and ambiguous space certainly influenced the shape of Debussy's music. At the same time, it should be noted that symbolism itself, the emphatic manifestation of which was the poem by Paul Verlaine The Art of Poetry (1980, p. 135), shaped its vision by referring to music as the ideal of art that expresses in the fullest and most perfect way 'the inexpressible'. It is difficult to speak of a cause and effect relationship in the discussed case. It is difficult to talk about any chronology of events. Shuffling individual elements in one series - the form of a work, its style, and means - correlate with shuffling in another. But it is not everything. On the one hand, the similarity between symbolism and Debussy's music is emphasized, and on the other, considering such compositions as Estampes or Arabesques, it is impossible to escape from the fine arts associations. The third cultural series of painting also plays its role here. The notion of modernism or avant-garde, the desire to go beyond the academic schemas, was certainly the driving force behind the actions of painters and composers. There would be no divisionism or pointillism, however, without the study of color perception by Michel Chevreul. Just as meditation on color led to the creation of a different organization of the image space (e.g. the aban- 
donment of the geometric perspective in favor of building depth with the use of color), Debussy's meditation on the timbre of sound, the methods of swelling and resonating chords, the color of the work obtained with the appropriate harmony led to the creation of a new definition of beauty in music. Rearranging items in one series resulted in regrouping in another. One might say that it comes down to correspondence and analogies in particular fields, and it will be true, but the point is to describe the cultural mechanism that generates change; which is a mechanism - let us repeat - structural and not genetic.

\section{Conclusion}

The principles of the conception of structural aesthetics presented here clearly require supplementation in the form of full demonstration material which would take into account both the idea of opposition and interference of cultural series. However, the 'segment' of the material given here provides an idea of the possibilities offered by this conception.

A structural interpretation of the history of aesthetics may be accused of simplifying and reducing the discussion to elementary markers chosen selectively and subjectively. However, I regard using research tools, even those which resonate with the not very poetic idea of a precise and predictable vision of culture, as one of the available possibilities in trying to achieve understanding of the phenomena and processes involved. It is the aim of research to capture that possibility and adapt it to the needs of acquiring knowledge.

Translated by Zofia Weaver

\section{References}

Hawkes, T. (1983). Strukturalizm i semiotyka [Structuralism and semiotics] (I. Sieradzki, Transl.). Warszawa: Państwowe Wydawnictwo Naukowe.

Holdcroft, D. (1991). Saussure. Signs, System and Arbitrariness. Cambridge: Cambridge University Press.

Jakobson, R., \& Halle, M. (1964). Podstawy języka [Fundamentals of language] (L. Zawadzki, Transl). Wrocław: Zakład Narodowy im. Ossolińskich.

Jakobson, R. (1989). W poszukiwaniu istoty języka [In search of the essence of language] vol. 1, vol. 2 (M. R. Mayenowa, Ed.). Warszawa: PIW.

Jarociński, S. (1966). Debussy a impresjonizm i symbolizm [Debussy, impressionism and symbolism]. Kraków: PWM.

Jarzębska, A. (2018). Spór o piękno muzyki [Debate on the beauty of music]. Toruń: Wydawnictwo Naukowe Uniwersytetu Mikołaja Kopernika.

Lévi-Strauss, C. (1973). Wprowadzenie do twórczości Marcela Maussa [Introduction to the works of Marcel Mauss]. In M. Mauss, Socjologia i antropologia [Sociology and anthropology] (M. Król, K. Pomian, J. Szacki, Transl.), (pp. 11-58). Warszawa: PIW. 
Lévi-Strauss C. (2000). Antropologia strukturalna [Structural anthropology] (K. Pomian, Transl.). Warszawa: Wydawnictwo KR.

Lisiecka, K. (2007). Symbolizm w teatrze Maeterlincka i Debussy'ego. O 'Pelleasie i Melisandzie' [Symbolism in the theatre of Maeterlinck and Debussy. On 'Pelleas et Melisande']. Muzykalia I, Materiaty konferencyjne I, Zeszyt francuski (materiały z konferencji muzykologicznej organizowanej przez Stowarzyszenie De Musica, Poznań, 25-26 kwietnia 2007), http://demusica.edu. pl/muzykalia-i-materialy-konferencyjne-1-zeszyt-francuski-1; accessed: 21.11.2020.

Mukařovský, J. (1970). Wśród znaków i struktur. Wybór szkiców [Among signs and structures. Selected essays] (J. Sławiński, Ed.). Warszawa: PIW.

Nowak, A. J. (2002). Świat człowieka. Znak. Wartość. Sztuka [The world of mankind. Sign. Value. Art]. Kraków: Collegium Collumbinum.

Pelc, J. (1982). Wstęp do semiotyki [Introduction to semiotics]. Warszawa: Wiedza Powszechna.

Piaget, J. (1972). Strukturalizm [Structuralism], (S. Cichowicz, Transl.). Warszawa: Wiedza Powszechna.

Saussure, F. de (2002). Kurs językoznawstwa ogólnego [Course in general linguistics], (K. Kasprzyk, Transl., K. Polański, Ed.). Warszawa: Państwowe Wydawnictwo Naukowe.

Saussure, F. de. (2004). Szkice z językoznawstwa ogólnego [Writings in general linguistics], (M. Danielewiczowa, Transl.). Warszawa: Wydawnictwo Akademickie DIALOG.

Szymańska, B. (1980). Co to jest strukturalizm? [What is structuralism?]. Wrocław: PAN.

Weinsberg, A., Kurkowska H. (Eds.). (1979). Językoznawstwo strukturalne [Structural linguistics]. Warszawa: Państwowe Wydawnictwo Naukowe.

Van Wymeersch, B. (1996). L'esthetique musicale de Descartes et le cartésianisme. Revue Philosophique de Louvain, 94(2): 271-293.

Verlaine, P. (1980). Wybór poezji [Selected poems] (M. Jastrun, Transl.). Wrocław: Zakład Narodowy im. Ossolińskich.

Żyłko, B. (2009). Semiotyka kultury. Szkoła tartusko-moskiewska [The semiotics of culture. TartuMoscow school]. Gdańsk: Wydawnictwo słowo/obraz terytoria. 